\title{
Screening of Glycerophospholipids Molecular Species Contents in Three North African Apricot (Prunus armeniaca L.) Seed Varieties
}

\author{
Aicha O. Cherif ${ }^{1 *}$, Marine De Person ${ }^{2}$, Mhamed Ben Messaouda ${ }^{1,3}$, \\ Manef Abderrabba ${ }^{1}$, and Fathi Moussa ${ }^{2}$ \\ ${ }^{1}$ Université de Carthage, Laboratoire Matériaux, Molécules et Applications, IPEST, B.P.51, 2075 La Marsa, TUNISIA \\ ${ }^{2}$ LETIAM, -Lip (Sys)2, EA 7357, Paris-Sud, Université Paris-Saclay, IUT d'Orsay, plateau de Moulon, F-91400, Orsay, FRANCE \\ ${ }^{3}$ Université de La Manouba, Institut Supérieur de Biotechnologie de Sidi-Thabet, BP-66, 2020, Sidi Thabet, Ariana, TUNISIA
}

\begin{abstract}
In the present work, a high-performance liquid chromatographic method coupled with mass spectrometry (HILIC-HPLC /ESI-MS) was used for the characterization and the quantification of glycerophospholipids (GPLs) classes and their molecular species in three genetically different Tunisian apricot cultivars (bitter, sweet and semi-sweet apricots). The application of the proposed method to the analysis of apricot oil allowed to separate and identify 74 molecular species of GPLs. Phosphatidylcholine (PC) class was found to be the most abundant GLPs in the three seed oils (38.6-62.4\%) especially in bitter apricot, followed by phosphatidylinositol (PI) and phosphatidylethanolamine (PE) classes with values of 8.338.9\% and $\mathbf{1 . 7 - 2 5 . 4 \%}$ respectively. Phosphatidic acid (PA), phosphatidylglycerol (PG) and lysophosphatidylcholine (LPC) compounds were minor ones with maximums of $11.3 \%, 9.8 \%$ and $9.2 \%$ respectively. The results we obtained for the three Tunisian apricot seed varieties clearly indicate that the phospholipids of Tunisian apricot are of great interest. In fact, the high content of phosphatidylcholine (PC) determines it as a suitable and valuable source for obtaining corresponding phospholipids concentrates.
\end{abstract}

Key words: bitter, sweet and semi-sweet apricots, fatty acids, glycerophospholipids, molecular species, HILIC- HPLC /ESI-MS

\section{Introduction}

Prunus armeniaca Vulgaris L., widely known as "apricot," is originally from China but arrived in Europe via Armenia where it has long been cultivated. It is an edible fruit mainly grown in Mediterranean climates ${ }^{1)}$. In Tunisia, two species of apricot plant coexist, i.e. wild variety Bargougs (bitter kernel apricot) propagated by seeds and grafted cultivars (sweet and semi-sweet kernel apricots). Bargougs are an integral part of the oasis cropping system ${ }^{2)}$. However, sweet and semi-sweet apricots cultivated in Testour(Northern Tunisia) are propagated by grafting and are favorable only in these conditions ${ }^{2}$. The cohabitation of plant materials propagated by grafting and seedling contributes to providing high heterogeneity ${ }^{2)}$. Krichen et $a l .{ }^{3)}$ demonstrated that in the case of grafted cultivars and Bargougs accessions, Tunisian apricot phylogeographical study showed a high genomic variability covering many regions of the country. Furthermore, genetically analyses elucidated also differences between different Tunisian apricot cultivars especially between sweet apricot and semi-sweet ones ${ }^{4}$.

Recently, and as a functional food, Prunus armeniaca has become an interesting product because of its nutritional and health benefits. It is also a rich source of oil, protein, soluble sugars, fiber, $\beta$-caroten, carbohydrates ${ }^{1)}$, as well as phospholipids (PLs) ${ }^{5-7)}$.

\footnotetext{
Abbreviations used : AprB: bitter wild apricot "Bargoug", AprC: sweet apricot "Chechi Bazza", AprO: semi-sweet apricot "Oud Rhayem", DAP: days after podding, EIC: extracted ion chromatogram, ESI-MS: electrospray-mass spectrometry, IS: immature stage, MS: full maturity stage, LC-MS: liquid chromatography-mass spectrometry, LPC: 1ysophosphatidylcoline, PA: phosphatidic acid, PC: phosphatidylcholine, PE : phosphatidylethanolamine, PG: glycerophospholipid, PI: phosphatidylinositol, PLs: phospholipid
}

*Correspondence to: Aicha O. Cherif, Université de Carthage, Laboratoire Matériaux, Molécules et Applications, IPEST, B.P.51, 2075 La Marsa, TUNISIA

E-mail: aicha.echerif@gmail.com

Accepted April 9, 2019 (received for review January 21, 2019)

Journal of Oleo Science ISSN 1345-8957 print / ISSN 1347-3352 online

http://www.jstage.jst.go.jp/browse/jos/ http://mc.manusriptcentral.com/jjocs 
Peculiarly, GPLs are the most significant class of polar lipids in foods, because they are an essential component of cell membranes in plant and animal tissues. In fact, they are produced in cell signaling and are, therefore, crucial for communication and interaction between body cells. Recent studies have shown that GPLs can have a valuable impact on human health, such as diminishing blood cholesterol levels as well as coronary heart diseases, cancer or inflammation $^{8)}$. Glycerophospholipids (GPLs) molecular species help membrane fusion and support cells from oxidation ${ }^{9)}$.

Natural GPLs can be classified into major classes of glycerophospholipids (GPLs, e.g. phosphatidylcholine) and sphingophospholipids (SPLs, e.g. sphingomyelin, in the brain and neural tissues ${ }^{10)}$. Basically, GPLs consist of a glycerol backbone which are esterified two fatty acids (FAs) on $s n-1$ and $s n-2$ positions and a polar head group with phosphate esterified at the $s n-3$ position to which a base, polyol, or amino acid is attached ${ }^{11)}$. Furthermore, GPLs can contain a different association and distribution of fatty acid esters, which this concomitant to significant distinct GPLs ${ }^{11}$. The overused GPLs classes of vegetable oils are phosphatidylcholine $(\mathrm{PC})$, phosphatidylethanolamine
(PE), phosphatidylglycerol (PG), phosphatidylinositol(PI), phosphatidic acid (PA) and lysophosphatidylcholine (LPC). They are synthesized via potential biosynthetic pathways (Fig. 1 ${ }^{10)}$. The classification of GPLs class is focused on molecules that have the same head group with different chain length and position of esterified fatty acids ${ }^{9)}$. The reason for such diversity is seemingly relates to their multiple functions.

In the literature, various methods have been reported for the monitoring of individual molecular species of phospholipids such as gas chromatography-mass spectrometry performance $(\mathrm{GC}-\mathrm{MS})^{12}$. Analysis of high-performance liquid chromatography ${ }^{13)}$, high liquid chromatography-mass spectrometry (HPLC-MS) ${ }^{14)}$, and supercritical fluid chromatography-mass spectrometry (SFC-MS ${ }^{15}$. Lately, Shrivas and Tapadia ${ }^{16)}$ employed matrix-assisted laser desorption time of flight(MALDI-TOF-MS) to analyze PLs in different types of samples. In MALDI-MS, the selection of a proper matrix is a very critical concern because of the preference of the matrix to ionize the particular type of analyte ${ }^{16)}$. Nowadays, MS detection allows in-depth characterization and precise quantification of PLs in different oil-

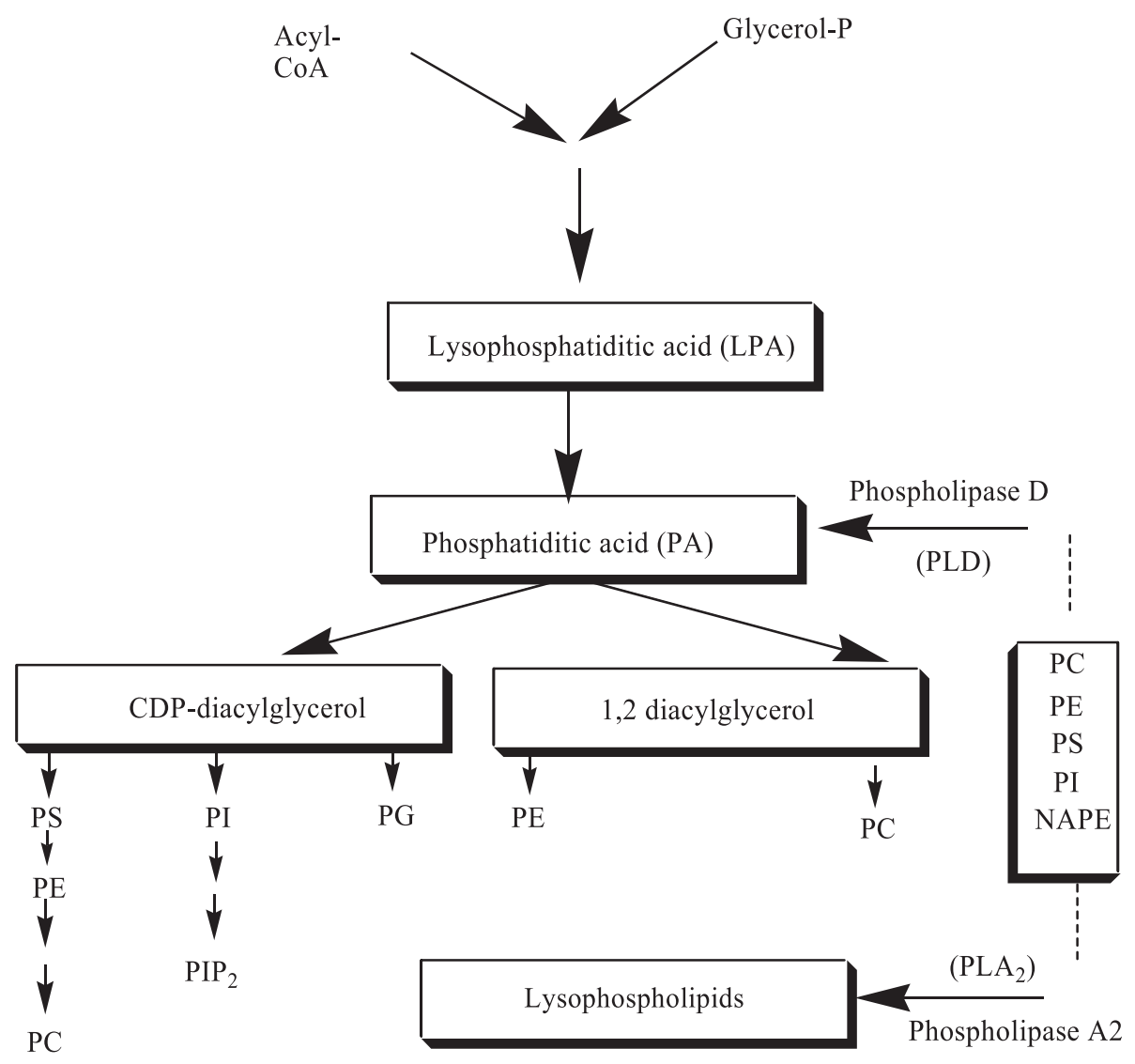

Fig.1 Potential biosynthetic pathways of phospholipids (E: ethanolamine; M: methyl; C: choline; P: phosphate; CDP: cytidine diphospho; PE: phosphatidylethanolamine; NAPE: Nacylphosphatidylethanolamine; PC: phosphatidylcholine; PS: phosphatidylserine; PI: phosphatidylinositol; IP: phosphatidylinositol phosphate; PIP $_{2}$ : phosphatidylinositol bisphosphate; PGP: phosphoglycerol phosphate; PG: phosphatidylglycerol; DPG: diphosphatidylglycerol). 
seeds. As a matter of fact, several studies have been done to analyze PLs of North African oilseeds by by LC/ESI-MS on corn oil ${ }^{24)}$, LC/MS on flaxeed oil ${ }^{26)}$ and LC/QTOF/MS on halophyte seed oils (Cakile maritima and Eryngium maritimum $)^{9)}$.

In the present work, hydrophilic interaction liquid chromatography (HILIC) coupled with electrospray ionization mass spectrometry (ESI-MS) was employed enabling the lipid class separation according to polarity like GPLs. This methodology offers some advantages over other liquid chromatography methods, since HILIC is more suitable with electrospray ionization compared to normal phase methods and resulted in higher sensitivity and improved peak shapes ${ }^{17)}$. As a result, HILIC-HPLC was considered as a strong and a robust method suitable for the identification and quantification of large number of phospholipids in olive oil $^{17)}$. Furthermore, this analytical method was successfully used to detect the loss in phospholipids in virgin olive oil ${ }^{17}$. Notwithstanding, apricot oil PLs have been poorly studied. Presently, the phospholipid composition of apricot oil has been reported, and many classes were identified: firstly, by fractionation of phospholipids on thin-layer chromatography $(\mathrm{TLC})^{5)}$, spectrophotometrically fractionation by twodirectional thin layer chromatography ${ }^{7}$ and nonaqueous capillary electrophoresis $(\mathrm{NACE})^{6}$. . Based on the progress achieved in lipids identification by mass spectrometry, we attempt to detect, identify and quantify different GPLs molecular species in Tunisian apricot oils from three genetically different cultivars and especially focused on two significant time-dates (immature and full maturity) stages.

\section{Materials and Methods}

\subsection{Reagents and standard}

HPLC grade solvents and chemical were purchased from Baker (Deventer, the Netherlands) and were used without further purification. Phospholipid standards (PC, PE, PG, PI, PA, LPC) acquired from Sigma -Aldrich (Madrid, Spain).

\subsection{Plant materials}

Three apricot varieties' (Prunus armeniaca L.) were tested: sweet apricot called "Chechi Bazza" (noted as AprC) and semi-sweet varieties called "Oud Rhayem" (noted as AprO). These varieties were originated from the Northern region of Tunisia (Testour), cultivated by grafting in a 5 ha area $(130 \times 300 \mathrm{~m})$ and genetically different as reported by Krichen ${ }^{3)}$. The third one was a wild bitter apricot called "Bargougs" (noted as AprB) originating from the South-West of Tunisia (Oasis of Gafsa) and cultivated by seed propagation in a 2 ha area $(40 \times 40 \mathrm{~m})$. The "Bargoug" oasis population was also genetically different from the last cultivars ones. Furthermore, these three apricot varieties are not yet biochemically studied ${ }^{3)}$. Each sample was col- lected at two time-dates of days podding (DAP), immature stage $\left(28^{\text {th }} \mathrm{DAP}\right)$ and full maturity stage $\left(55^{\text {th }} \mathrm{DAP}\right)$. Seeds $(2$ $\mathrm{kg}$ ) collected from each cultivar's species were kept in aerated plastic bags and transported to laboratory for further analysis.

\subsection{Lipid extraction}

The total lipids were extracted by the method of Folch ${ }^{18)}$ and modified by Bligh \& Dyer ${ }^{19}$. . Kernels $(2.5 \mathrm{~g})$ were washed with boiling water for 5 min to denature the phospholipase ${ }^{20)}$ and then crushed in a mortar with a mixture of $\mathrm{CHCl}_{3}-\mathrm{MeOH}(2: 1 \mathrm{~V} / \mathrm{V})$. The fixing water was added, and the homogenate was centrifuged at $3000 \mathrm{~g}$ for $15 \mathrm{~min}$. The lower organic phase containing the total lipids was kept and dried under a stream of nitrogen.

\subsection{Analysis of fatty acid composition by GC-FID}

The fatty acid composition of the seed oil was determined by gas chromatography of fatty acid methyl esters. Fatty acid methyl esters were prepared by simultaneous extraction and methylation following the procedure described by Mectalfe $\mathrm{f}^{21)}$ modified by Lechvallier ${ }^{22)}$. Fatty acid methyl esters were analyzed by gas chromatography (GC) using a HP 4890 chromatograph equipped with a flame ionisation detector (FID) on a capillary column coated with Supelco (Sigma-Aldrich, Taufkirchen, Germany) (30 m length, $0.25 \mathrm{~mm}$ id, $0.2 \mathrm{~lm}$ film thickness). Column temperature was programmed from 150 to $200^{\circ} \mathrm{C}$ with $4^{\circ} \mathrm{C} / \mathrm{min}$. Temperatures of detector and auto injector were 250 and $230^{\circ} \mathrm{C}$, respectively. $\mathrm{H} 2$ was used as a carrier gas with a flow rate of $7 \mathrm{ml} / \mathrm{min}$. The fatty acids were identified by comparison of their retention times with those of standards. The quantitative evaluation was carried out on the base of gas chromatography peak areas of the different methyl esters.

\subsection{Phospholipids extraction}

The phospholipids were extracted as reported by Xiong ${ }^{17)}$. Briefly, $200 \mathrm{mg}$ of apricot oil was dissolved in 1 $\mathrm{mL}$ CHCL-MeOH (2:1 V/V) mixture and then evaporated. $500 \mu \mathrm{L}$ of the mobile phase was added (92/8 acetonitrile/125 mM ammonium formate $\mathrm{pH} 3.0$ (A) and $10 \mathrm{mM}$ ammonium formate dissolved in water with $0.2 \%$ formic acid $\mathrm{pH} 3.0$ (B). The homogenate was centrifuged at $3000 \mathrm{~g}$ for $15 \mathrm{~min}$. Finally, $100 \mu \mathrm{L}$ of the supernatant was dissolved in $900 \mu \mathrm{L}$ of the mobile phase, homogenated and injected $(10 \mu \mathrm{L})$ into the HPLC apparatus.

\subsection{HPLC and HPLC-MS}

LC-MS experiments were performed using a method described in detail elsewhere ${ }^{17,23)}$. The method employed an Agilent 1100 LC system(Agilent Technologies, Palo Alto, CA) coupled to a Thermo TSQ Quantum Ultra triple quadrupole (Thermo, Scientific, ZI, Courtaboeuf, France). The 
phospholipid fractions from apricot seeds were separated using a Kinetex HILIC column $(2.6 \mu \mathrm{m}, 100 \AA, 150 \times 2,-1$ $\mathrm{mm})$. The mobile phases consisted of (A) a mixture of $\mathrm{pH}$ 3.0 acetonitrile/125 $\mathrm{mM}$ ammonium formate $(92 / 8, \mathrm{v} / \mathrm{v})$ and (B) a $\mathrm{pH} 3.0,10 \mathrm{mM}$ ammonium formate solution. The solvent gradient initiated at $0 \%(\mathrm{~B})$, increased to $16 \%$ (B) in $12 \mathrm{~min}$, to $70 \% \mathrm{~B}$ in $0.1 \mathrm{~min}$ and then maintained at $70 \%(\mathrm{~B})$ until the next injection ${ }^{17,23)}$. The injection volume was $5 \mu \mathrm{L}$ and the flow rate was $200 \mu \mathrm{L} / \mathrm{min}$. MS analysis of phospholipids was performed using ESI in the negative and positive modes. We used nitrogen as sheath gas, ion sweep gas and auxiliary gas. The instrumental settings were as follows: spray voltage $-4000 \mathrm{~V}$, sheath gas flow rate 10 ; ion sweep gas flow rate 2 ; auxiliary gas flow rate 5 arbitrary units) and ion source temperature $200^{\circ} \mathrm{C}$. XCalibur software was used for data acquisition and analysis. Relative concentrations of each phospholipids class and species were estimated using peak areas of extracted ion chromatograms (EIC).

Identification of phospholipids was done by comparing of their chromatographic retention times with those of standard compounds. Quantification of the different molecular species within each phospholipid class was carried out by obtaining the peak areas for the individual extracted ion chromatograms ${ }^{24)}$. The exact masses of 43 molecular species of parental ions, MS-MS fragments of each GPLs class are found in Table 3.

\subsection{Statistical analysis}

The statistical analysis was performed by using the Proc ANOVA in SAS (software version 8). Duncan's multiple range test was used. All measurements were made after triplicate extraction and each extraction was injected five times.

\section{Results and Discussion}

3.1 Oil yields

Oil contents of our three-apricot species are given in
Table 1. Table 1 shows also the percentage of the total oil content and total phospholipids content in the apricot oil and expressed on the total lipid and on dry weight. Results showed that oil content of apricot species varied from $20.5 \%$ to $31.5 \%$ respectively from bitter and sweet apricot at immature stage. At full maturity, the maximums were reached from 39.7 to $50.5 \%$ of oils respectively in bitter and sweet ones. Bitter and sweet apricot had relatively high seed-oil content. Comparatively, the oil content of other oilseeds plants (soybean, safflower, sesame and sunflower) ranged from 19 to $49 \%{ }^{9)}$.

Furthermore, the fatty acid content of the three apricot varieties is shown in Table 2. Significant differences $(p<$ 0.05) in fatty acid composition of apricot oil were observed between the three species. Apricot oils were characterized by a high level of total unsaturated fatty acids (UFAs) accounting for $85.72 \%, 82.43 \%$ and $82.08 \%$ of total lipids in bitter, sweet and semi-sweet apricot, respectively (Table 2). Saturated fatty acids (SFAs) are less abundant than UFAs with only $7.62 \%, 7.09 \%$ and $6.24 \%$ of bitter, semisweet and sweet apricot, respectively (Table 2). Oleic acid (C18:1) was the most predominant fatty acid contributing to a maximum of $61.87 \%$ reached in bitter one, followed by linoleic acid (C18:2) as 38.64\% and palmitic acid(C16:0) as $6.79 \%$ (Table 2). Recent studies confirmed that the quality of the oil depends on the number of unsaturation present in fatty acids chain. This property is related to its benefits such as cardiovascular diseases and cholesterol reduction ${ }^{9)}$. Our results (Table 2) showed less amounts of very long chain unsaturated fatty acid 20 carbon atoms, arachidic (C20:0) and gadoleic acids (C20:1) attempting to 0.09\% and $0.08 \%$ in bitter species (Table 2). Khotimchenko et al. ${ }^{25)}$ reported that the lipid and fatty acid composition and content are affected by the type of species, genetic differences, habitat conditions, season, and locations. In our study (Table 2), regardless of biotope and maturity stage, quantitative and qualitative differences in fatty acid composition in the three apricot cultivars can be attributed basically to the genetic difference relating to the species.

Table 1 Phospholipid and oil content in three varieties of apricot at two maturity stages.

\begin{tabular}{|c|c|c|c|c|c|c|c|c|c|c|}
\hline $\begin{array}{l}\text { Stages of } \\
\text { maturity }\end{array}$ & arieties & $\begin{array}{l}\text { Oil } \\
(\%)\end{array}$ & $\begin{array}{c}\text { PL } \\
\text { (\% oil) }\end{array}$ & $\begin{array}{c}\text { PL } \\
\text { (\% of DW) }\end{array}$ & $\begin{array}{l}\text { PG } \\
(\% \mathrm{PL})\end{array}$ & $\begin{array}{c}\mathrm{PA} \\
(\% \mathrm{PL})\end{array}$ & $\begin{array}{c}\mathrm{PE} \\
(\% \mathrm{PL})\end{array}$ & $\begin{array}{c}\text { PI } \\
(\% \mathrm{PL})\end{array}$ & $\begin{array}{c}\mathrm{PC} \\
(\% \mathrm{PL})\end{array}$ & $\begin{array}{l}\text { LPC } \\
(\% \text { PL) }\end{array}$ \\
\hline \multirow{3}{*}{$\begin{array}{c}\text { IS } \\
\text { (28 DAP) }\end{array}$} & & $31.5 \pm 0.04^{\mathrm{a}}$ & $23 \pm 0.64^{b}$ & $16.5 \pm 0.02^{\mathrm{a}}$ & $8.2 \pm 0.1^{\mathrm{a}}$ & $8.4 \pm 0.6^{b}$ & $1.7 \pm 0.5^{\mathrm{b}}$ & $9.9 \pm 0.5^{b}$ & $62.4 \pm 1.3^{\mathrm{a}}$ & $4.3 \pm 0.6^{\mathrm{a}}$ \\
\hline & AprO & $23.2 \pm 0.04^{\mathrm{a}}$ & $13.4 \pm 0.02^{\mathrm{b}}$ & $5.2 \pm 0.07^{\mathrm{a}}$ & $8.2 \pm 0.4^{\mathrm{a}}$ & $11.3 \pm 0.8^{b}$ & $25.4 \pm 0.3^{\mathrm{a}}$ & $10.0 \pm 1.3^{\mathrm{c}}$ & $44.4 \pm 0.1^{\mathrm{b}}$ & $1.1 \pm 0.5^{\mathrm{a}}$ \\
\hline & AprC & $20.5 \pm 0.07^{\mathrm{b}}$ & $12 \pm 0.14^{\mathrm{b}}$ & $7.8 \pm 0.04^{\mathrm{a}}$ & $5.4 \pm 0.7^{\mathrm{b}}$ & $1.6 \pm 0.3^{\mathrm{b}}$ & $14.5 \pm 0.2^{\mathrm{b}}$ & $22.3 \pm 0.3^{\mathrm{a}}$ & $47.0 \pm 0.3^{\mathrm{c}}$ & $9.2 \pm 0.1^{\mathrm{a}}$ \\
\hline \multirow{3}{*}{$\begin{array}{c}\text { MS } \\
\text { (55 DAP) }\end{array}$} & & $39.7 \pm 0.02^{\mathrm{a}}$ & $2.3 \pm 0.02^{b}$ & $1.3 \pm 0.00^{\mathrm{a}}$ & $9.8 \pm 0.4^{\mathrm{b}}$ & $1.2 \pm 0.1^{b}$ & $8.9 \pm 0.2^{\mathrm{a}}$ & $38.9 \pm 0.2^{\mathrm{a}}$ & $38.6 \pm 0.1^{b}$ & $2.1 \pm 0.9^{b}$ \\
\hline & AprO & $42.5 \pm 0.01^{\mathrm{a}}$ & $3.1 \pm 0.01^{\mathrm{a}}$ & $1.2 \pm 0.00^{\mathrm{a}}$ & $6.2 \pm 1.5^{\mathrm{b}}$ & $2.2 \pm 0.9^{b}$ & $15.5 \pm 1.3^{\mathrm{a}}$ & $8.3 \pm 0.5^{\mathrm{a}}$ & $62.2 \pm 0.7^{\mathrm{a}}$ & $4.2 \pm 0.3^{b}$ \\
\hline & AprC & $50.5 \pm 0.03^{\mathrm{b}}$ & $3.6 \pm 0.01^{\mathrm{a}}$ & $1.1 \pm 0.00^{\mathrm{a}}$ & $7.5 \pm 0.1^{\mathrm{a}}$ & $1.5 \pm 0.2^{\mathrm{a}}$ & $6.3 \pm 0.1^{\mathrm{b}}$ & $27.6 \pm 0.2^{\mathrm{a}}$ & $55.9 \pm 0.2^{\mathrm{d}}$ & $7.2 \pm 0.1^{\mathrm{a}}$ \\
\hline
\end{tabular}

The values are the mean of three replicates \pm standard deviation.

Means followed by different letters in the same row denote that they are significantly different at $p<0.05$. DAP: days after podding; AprB: wild apricot; AprC: sweet apricot; AprO: semi-sweet apricot; DW: dry weight, PL: phospholipids. 
Table 2 Oil, fatty acids contents in three varieties of apricot at full maturity stage.

\begin{tabular}{|c|c|c|c|}
\hline & Wild & sweet & Semi-sweet \\
\hline & \multicolumn{3}{|c|}{ Oil (\% of DW) } \\
\hline & $39.70 \pm 0.02^{\mathrm{a}}$ & $50.50 \pm 0.03^{\mathrm{b}}$ & $42.50 \pm 0.01^{\mathrm{a}}$ \\
\hline & \multicolumn{3}{|c|}{ Fatty acids (\%) } \\
\hline $\mathrm{C} 16: 0$ & $5.67 \pm 0.40^{\mathrm{a}}$ & $5.58 \pm 0.90^{\mathrm{a}}$ & $6.79 \pm 0.44^{\mathrm{a}}$ \\
\hline $\mathrm{C} 17: 1$ & $0.10 \pm 0.03^{\mathrm{b}}$ & $0.11 \pm 0.07^{\mathrm{a}}$ & $0.10 \pm 0.03^{\mathrm{a}}$ \\
\hline $\mathrm{C} 16: 1$ & $0.03 \pm 0.25^{\mathrm{a}}$ & $0.62 \pm 0.05^{\mathrm{b}}$ & $0.87 \pm 0.03^{\mathrm{b}}$ \\
\hline $\mathrm{C} 18: 0$ & $1.33 \pm 0.27^{\mathrm{a}}$ & $0.59 \pm 0.05^{\mathrm{b}}$ & $0.76 \pm 0.025^{\mathrm{a}}$ \\
\hline $\mathrm{C} 18: 1 \Delta-9$ & $61.87 \pm 1.13^{\mathrm{a}}$ & $48.97 \pm 1.37^{\mathrm{b}}$ & $42.32 \pm 1.13^{\mathrm{b}}$ \\
\hline $\mathrm{C} 18: 2$ & $23.44 \pm 1.33^{\mathrm{b}}$ & $32.47 \pm 0.41^{\mathrm{a}}$ & $38.65 \pm 1.35^{b}$ \\
\hline $\mathrm{C} 18: 3$ & $0.20 \pm 0.02^{b}$ & $0.06 \pm 0.02^{\mathrm{a}}$ & $0.09 \pm 0.03^{b}$ \\
\hline $\mathrm{C} 20: 0$ & $0.09 \pm 0.03^{b}$ & $0.07 \pm 0.02^{\mathrm{a}}$ & $0.07 \pm 0.02^{\mathrm{a}}$ \\
\hline $\mathrm{C} 20: 1$ & $0.08 \pm 0.01^{\mathrm{a}}$ & $0.20 \pm 0.07^{\mathrm{a}}$ & $0.08 \pm 0.27^{\mathrm{b}}$ \\
\hline SFA & $7.09 \pm 0.40^{\mathrm{a}}$ & $6.24 \pm 0.44^{\mathrm{a}}$ & $7.62 \pm 0.03^{b}$ \\
\hline UFA & $85.72 \pm 0.41^{\mathrm{a}}$ & $82.43 \pm 0.24^{\mathrm{b}}$ & $82.08 \pm 0.13^{\mathrm{b}}$ \\
\hline
\end{tabular}

The values are the mean of three replicates \pm standard deviation. Means followed by different letters in the same row denote that they are significantly different at $p<0.05$. AprB: wild apricot; AprC: sweet apricot; AprO: semi-sweet apricot; DW: dry weight.

\subsection{Phospholipid content}

Table 1 shows the percentage of total phospholipids (PLs) content in the apricot oil and expressed on the total lipid and on dry weight. Comparatively to oil contents, PLs results showed the content varied from $12 \%$ to $23 \%$ respectively from bitter and sweet apricot at immature stage. It varied from 7.8 to $16.5 \%$ on a dry weight (DW) at immature stage and 1.1 to $1.3 \%$ on a dry weight at full maturity one. Interestingly, at immature stage, bitter apricot represents the richest cultivars on total lipids and PLs contents, whereas at full maturity, sweet one represents the interesting cultivars. During these two time-dates, PLs percentages show a continuous decrease, whereas, the oil content increases significantly and reached a maximum of $50 \%$ especially in sweet apricot. This decrease during apricot's seed development suggests higher relative proportions of membrane components in immature seeds than in mature seeds. Herchi et $a l^{26}{ }^{26}$ indicates that the role of biosynthesized PLs in immature seeds is related to the formation of biological membranes and triacylglycerols constitution. PLs contents in the three apricot cultivars were higher than those reported by Zlatanov and Janakieva ${ }^{7}$ in apricot on oil and on dry weight and also in corn oil (0.1 to $0.3 \%$ on dry weight $)^{24)}$ and in flaxseed oil (1.8 to $2.5 \%$ of the total lipids $)^{26)}$.

\subsection{Separation of glycerophospholipid classes and their different molecular species}

The used method allows the quantification of six lipid classes using relative abundances of specific ions in the negative ion ESI mass spectra. The relative abundance of the different observed GPLs classes is reported in Table 3. Figure 2 shows six well-separated glycerophospholipids classes phosphatidylglycerol (PG), phosphatidic acid(PA), phosphatidylethanolamine (PE), phosphatidylinositol(PI), phosphatidylcholine (PC) and lysophosphatidylcholine (LPC). For each chromatographic peak, the mass spectra of PG, PA, PI and PE show ions corresponding to molecular proton $[\mathrm{M}-\mathrm{H}]^{-}$ion adducts. However, the mass spectra of PC and LPC show ions corresponding to carboxylate $[\mathrm{M}+$ $\mathrm{HCOO}^{-}$ion adducts. The adduction results for PE species with $[\mathrm{M}-\mathrm{H}]^{-}$ion at $\mathrm{m} / \approx 744$, two dominant fragment ions with $m / z 283$ and 281, confirming the presence of stearic (C18:0) and oleic (C18:1) fatty acids respectively. As well as, the PE species with $\mathrm{m} / z 738$ gave three major fragments with $\mathrm{m} / z 279$ (more intense), 281 and 277 and indicates that the same fatty acid chain linoleic acid (C18:2) is present at both $s n-1$ and $s n-2$ position of the phospholipids. However, in PC species with $[\mathrm{M}+\mathrm{HCOO}]^{-}$ion at $\mathrm{m} / \mathrm{z}$ 830 results three dominant fragment ions with $\mathrm{m} / z 279$, 283 and 281 (more intense) corresponding respectively to linoleic (C18:2), stearic (C18:0) and oleic (C18:1) fatty acids. Additionally, LPC species with an $[\mathrm{M}+\mathrm{HCOO}]^{-}$ion at $\mathrm{m} / z$ 540 gave only one carboxylate anion with $\mathrm{m} / \approx 255$ corresponding to palmitic (C16:0) fatty acid chain. By this analogy, the different fatty acid chains were identified among the various classes of PLs species present in apricot oil.

Results in Table 1 show significant differences $(p<0.05)$ in PA, PG, PE, PI, PC and LPC contents of the three apricot varieties. The differences in catalyzing enzymes activities of PL's biosynthesis could explain the various abundance of PLs classes in the three plants. In immature stage, the main PLs classes in our apricot oil varieties were PC, PE and PI accounting respectively for 44.4-62.4\% (of total PL), 1.7 - 25.4\% (of total PL) and 9.9- 22.3\% (of total PL) (Table 1). At full maturity, the levels of PC, PE and PI changed respectively at $38.6-62.2 \%$ (of total PL), 6.3 15.5\% (of total PL) and 8.3-38.9\% (of total PL) and still the major compounds in GPLs fraction of apricot oils. PC was overabundant GPLs class in both seed oils, amounting at full maturity more than $62.2 \%, 55.9 \%$ and $38.6 \%$ of total GPLs content in sweet, semi-sweet and bitter apricot respectively. LPC (2.1-7.2\%), PA (1.2-2.2\%) and PG (6.2$9.8 \%)$ were found to be present in low concentrations in the three cultivars. The seeds collected at the same stage of maturity have quite homogenous PL classes predominance instead the genetical differences between the three species. However, profiles of PA, PG, PE, PI, PC and LPC molecular species were significantly different $(p<0.05)$ between the three cultivars during maturity (Table 4$)$.

3.3.1 Phosphatidylglycerol(PG)

Phosphatidylglycerol or PG molecular species in the 
Table 3 Glycerophospholipids classes identified in Apricot oil by HILIC-HPLC/ESI-MS ${ }^{2}$, retention times, relative abundance and observed ions.

\begin{tabular}{|c|c|c|c|c|c|c|c|c|c|}
\hline \multirow[b]{2}{*}{ M } & \multicolumn{3}{|c|}{ PG (4-5min) } & \multicolumn{3}{|c|}{ PA (6-7min) } & \multicolumn{3}{|c|}{ PI (7-8min) } \\
\hline & Formula $(\mathrm{M})^{\mathrm{a}}$ & {$[\mathrm{M}-\mathrm{H}]^{-\mathrm{b}}$} & $\begin{array}{c}\mathrm{MS} / \mathrm{MS} \\
(\mathrm{m} / \mathrm{z})\end{array}$ & Formula $(\mathrm{M})^{\mathrm{a}}$ & {$[\mathrm{M}-\mathrm{H}]^{-\mathrm{b}}$} & $\begin{array}{c}\mathrm{MS} / \mathrm{MS} \\
(\mathrm{m} / \mathrm{z})\end{array}$ & Formula $(\mathrm{M})^{\mathrm{a}}$ & {$[\mathrm{M}-\mathrm{H}]^{-\mathrm{b}}$} & $\begin{array}{c}\mathrm{MS} / \mathrm{MS} \\
(\mathrm{m} / \mathrm{z})\end{array}$ \\
\hline $32: 0$ & $\mathrm{C}_{38} \mathrm{H}_{75} \mathrm{O}_{10} \mathrm{P}$ & 721.502533 & 551.503375 & $\mathrm{C}_{35} \mathrm{H}_{69} \mathrm{O}_{8} \mathrm{P}$ & 647.476775 & 551.503375 & $\mathrm{C}_{41} \mathrm{H}_{79} \mathrm{O}_{13} \mathrm{P}$ & 809.52 & 551.503375 \\
\hline $34: 0$ & $\mathrm{C}_{40} \mathrm{H}_{79} \mathrm{O}_{10} \mathrm{P}$ & 749.534733 & 579.534675 & $\mathrm{C}_{37} \mathrm{H}_{73} \mathrm{O}_{8} \mathrm{P}$ & 675.508075 & 579.534675 & $\mathrm{C}_{43} \mathrm{H}_{83} \mathrm{O}_{13} \mathrm{P}$ & 837.55 & 579.534675 \\
\hline $34: 1$ & $\mathrm{C}_{40} \mathrm{H}_{77} \mathrm{O}_{10} \mathrm{P}$ & 747.522148 & 766.559225 & $\mathrm{C}_{37} \mathrm{H}_{71} \mathrm{O}_{8} \mathrm{P}$ & 673.482425 & 577.519025 & $\mathrm{C}_{43} \mathrm{H}_{81} \mathrm{O}_{13} \mathrm{P}$ & 835.53 & 577.519025 \\
\hline $34: 2$ & $\mathrm{C}_{40} \mathrm{H}_{75} \mathrm{O}_{10} \mathrm{P}$ & 745.502569 & 575.503375 & $\mathrm{C}_{37} \mathrm{H}_{69} \mathrm{O}_{8} \mathrm{P}$ & 671.476775 & 575.503375 & $\mathrm{C}_{43} \mathrm{H}_{79} \mathrm{O}_{13} \mathrm{P}$ & 833.52 & 575.503375 \\
\hline $36: 1$ & $\mathrm{C}_{42} \mathrm{H}_{81} \mathrm{O}_{10} \mathrm{P}$ & 775.554736 & 605.550325 & $\mathrm{C}_{37} \mathrm{H}_{67} \mathrm{O}_{8} \mathrm{P}$ & 669.45 & 573.487725 & $\mathrm{C}_{43} \mathrm{H}_{77} \mathrm{O}_{13} \mathrm{P}$ & 831.50 & 573.487725 \\
\hline $36: 2$ & $\mathrm{C}_{42} \mathrm{H}_{79} \mathrm{O}_{10} \mathrm{P}$ & 773.532589 & 603.534675 & $\mathrm{C}_{39} \mathrm{H}_{77} \mathrm{O}_{8} \mathrm{P}$ & 703.53 & 607.565975 & $\mathrm{C}_{45} \mathrm{H}_{87} \mathrm{O}_{13} \mathrm{P}$ & 865.58 & 607.565975 \\
\hline $36: 3$ & $\mathrm{C}_{42} \mathrm{H}_{77} \mathrm{O}_{10} \mathrm{P}$ & 771.522175 & 601.519025 & $\mathrm{C}_{39} \mathrm{H}_{74} \mathrm{O}_{8} \mathrm{P}$ & 701.51 & 605.550325 & $\mathrm{C}_{45} \mathrm{H}_{85} \mathrm{O}_{13} \mathrm{P}$ & 863.56 & 605.550325 \\
\hline $36: 4$ & $\mathrm{C}_{42} \mathrm{H}_{75} \mathrm{O}_{10} \mathrm{P}$ & 769.502358 & 599.503375 & $\mathrm{C}_{39} \mathrm{H}_{73} \mathrm{O}_{8} \mathrm{P}$ & 699.50 & 603.534675 & $\mathrm{C}_{45} \mathrm{H}_{83} \mathrm{O}_{13} \mathrm{P}$ & 861.55 & 603.534675 \\
\hline $36: 4$ & $\mathrm{C}_{42} \mathrm{H}_{75} \mathrm{O}_{10} \mathrm{P}$ & 769.503369 & 599.503375 & $\mathrm{C}_{39} \mathrm{H}_{73} \mathrm{O}_{8} \mathrm{P}$ & 699.50 & 603.534675 & $\mathrm{C}_{45} \mathrm{H}_{81} \mathrm{O}_{13} \mathrm{P}$ & 859.53 & 601.519025 \\
\hline $36: 5$ & $\mathrm{C}_{42} \mathrm{H}_{73} \mathrm{O}_{10} \mathrm{P}$ & 767.494588 & 597.487725 & $\mathrm{C}_{39} \mathrm{H}_{71} \mathrm{O}_{8} \mathrm{P}$ & 697.48 & 601.519025 & $\mathrm{C}_{45} \mathrm{H}_{83} \mathrm{O}_{13} \mathrm{P}$ & 861.55 & 603.534675 \\
\hline $36: 6$ & $\mathrm{C}_{42} \mathrm{H}_{71} \mathrm{O}_{10} \mathrm{P}$ & 765.478115 & 595.472075 & $\mathrm{C}_{39} \mathrm{H}_{71} \mathrm{O}_{8} \mathrm{P}$ & 697.48 & 601.519025 & $\mathrm{C}_{45} \mathrm{H}_{81} \mathrm{O}_{13} \mathrm{P}$ & 859.53 & 601.519025 \\
\hline $36: 7$ & & & & $\mathrm{C}_{39} \mathrm{H}_{69} \mathrm{O}_{8} \mathrm{P}$ & 695.47 & 599.503375 & $\mathrm{C}_{45} \mathrm{H}_{79} \mathrm{O}_{13} \mathrm{P}$ & 857.52 & 599.503375 \\
\hline $36: 7$ & & & & $\mathrm{C}_{39} \mathrm{H}_{69} \mathrm{O}_{8} \mathrm{P}$ & 695.47 & 599.503375 & $\mathrm{C}_{45} \mathrm{H}_{75} \mathrm{O}_{13} \mathrm{P}$ & 853.49 & 595.472075 \\
\hline $36: 8$ & & & & $\mathrm{C}_{39} \mathrm{H}_{67} \mathrm{O}_{8} \mathrm{P}$ & 693.45 & 597.487725 & $\mathrm{C}_{45} \mathrm{H}_{79} \mathrm{O}_{13} \mathrm{P}$ & 857.52 & 599.503375 \\
\hline \multirow[t]{18}{*}{$36: 9$} & & & & $\mathrm{C}_{39} \mathrm{H}_{65} \mathrm{O}_{8} \mathrm{P}$ & 691.43 & 595.472075 & $\mathrm{C}_{45} \mathrm{H}_{77} \mathrm{O}_{13} \mathrm{P}$ & 855.50 & 597.487725 \\
\hline & \multicolumn{3}{|c|}{ PE (8-10min) } & \multicolumn{3}{|c|}{ PC (11-13min) } & \multicolumn{3}{|c|}{ LPC (14-16min) } \\
\hline & Formula $(\mathrm{M})^{\mathrm{a}}$ & {$[\mathrm{M}-\mathrm{H}]^{-\mathrm{b}}$} & $\begin{array}{c}\text { MS/MS } \\
(\mathrm{m} / \mathrm{z})\end{array}$ & Formula $(\mathrm{M})^{\mathrm{a}}$ & {$[\mathrm{M}+\mathrm{HCCO}]^{-\mathrm{b}}$} & $\begin{array}{c}\text { MS/MS } \\
(\mathrm{m} / \mathrm{z})\end{array}$ & Formula $(\mathrm{M})^{\mathrm{a}}$ & {$[\mathrm{M}+\mathrm{HCCO}]^{-\mathrm{b}}$} & $\begin{array}{c}\mathrm{MS} / \mathrm{MS} \\
(\mathrm{m} / \mathrm{z})\end{array}$ \\
\hline & $\mathrm{C}_{39} \mathrm{H}_{78} \mathrm{O}_{8} \mathrm{P}$ & 718.54 & 720.554332 & $\mathrm{C}_{40} \mathrm{H}_{76} \mathrm{O}_{8} \mathrm{P}$ & 778.56 & 550.496082 & $\mathrm{C}_{24} \mathrm{H}_{50} \mathrm{O}_{7} \mathrm{PN}$ & 540.33 & 282. \\
\hline & $\mathrm{C}_{39} \mathrm{H}_{76} \mathrm{O}_{8} \mathrm{P}$ & 716.52 & 718.538682 & $\mathrm{C}_{42} \mathrm{H}_{84} \mathrm{O}_{8} \mathrm{P}$ & 806.59 & 578.527382 & $\mathrm{C}_{26} \mathrm{H}_{54} \mathrm{O}_{7} \mathrm{PN}$ & 568.36 & 280. \\
\hline & $\mathrm{C}_{39} \mathrm{H}_{74} \mathrm{O}_{8} \mathrm{P}$ & 714.51 & 716.523032 & $\mathrm{C}_{42} \mathrm{H}_{82} \mathrm{O}_{8} \mathrm{P}$ & 804.58 & 576.511732 & $\mathrm{C}_{26} \mathrm{H}_{52} \mathrm{O}_{7} \mathrm{PN}$ & 566.35 & 278. \\
\hline & $\mathrm{C}_{39} \mathrm{H}_{72} \mathrm{O}_{8} \mathrm{P}$ & 712.49 & 714.507382 & $\mathrm{C}_{42} \mathrm{H}_{80} \mathrm{O}_{8} \mathrm{P}$ & 802.56 & 574.496082 & $\mathrm{C}_{26} \mathrm{H}_{50} \mathrm{O}_{7} \mathrm{PN}$ & 564.33 & 276. \\
\hline & $\mathrm{C}_{41} \mathrm{H}_{80} \mathrm{O}_{8} \mathrm{P}$ & 744.55 & 746.569982 & $\mathrm{C}_{42} \mathrm{H}_{78} \mathrm{O}_{8} \mathrm{P}$ & 800.54 & 572.480432 & $\mathrm{C}_{26} \mathrm{H}_{48} \mathrm{O}_{7} \mathrm{PN}$ & 562.31 & 274. \\
\hline & $\mathrm{C}_{41} \mathrm{H}_{78} \mathrm{O}_{8} \mathrm{P}$ & 742.54 & 744.554332 & $\mathrm{C}_{44} \mathrm{H}_{88} \mathrm{O}_{8} \mathrm{P}$ & 834.62 & 606.558682 & & & \\
\hline & $\mathrm{C}_{41} \mathrm{H}_{76} \mathrm{O}_{8} \mathrm{P}$ & 740.52 & 742.538682 & $\mathrm{C}_{44} \mathrm{H}_{86} \mathrm{O}_{8} \mathrm{P}$ & 832.61 & 604.543032 & & & \\
\hline & $\mathrm{C}_{41} \mathrm{H}_{78} \mathrm{O}_{8} \mathrm{P}$ & 742.54 & 744.554332 & $\mathrm{C}_{44} \mathrm{H}_{84} \mathrm{O}_{8} \mathrm{P}$ & 830.59 & 602.527382 & & & \\
\hline & $\mathrm{C}_{41} \mathrm{H}_{76} \mathrm{O}_{8} \mathrm{P}$ & 740.52 & 742.538682 & $\mathrm{C}_{44} \mathrm{H}_{82} \mathrm{O}_{8} \mathrm{P}$ & 828.58 & 600.511732 & & & \\
\hline & $\mathrm{C}_{41} \mathrm{H}_{74} \mathrm{O}_{8} \mathrm{P}$ & 738.51 & 740.523032 & $\mathrm{C}_{44} \mathrm{H}_{84} \mathrm{O}_{8} \mathrm{P}$ & 830.59 & 602.527382 & & & \\
\hline & $\mathrm{C}_{41} \mathrm{H}_{74} \mathrm{O}_{8} \mathrm{P}$ & 738.51 & 740.523032 & $\mathrm{C}_{44} \mathrm{H}_{82} \mathrm{O}_{8} \mathrm{P}$ & 828.58 & 600.511732 & & & \\
\hline & $\mathrm{C}_{41} \mathrm{H}_{72} \mathrm{O}_{8} \mathrm{P}$ & 736.49 & 738.507382 & $\mathrm{C}_{44} \mathrm{H}_{80} \mathrm{O}_{8} \mathrm{P}$ & 826.54 & 598.496082 & & & \\
\hline & $\mathrm{C}_{41} \mathrm{H}_{70} \mathrm{O}_{8} \mathrm{P}$ & 734.48 & 736.491732 & $\mathrm{C}_{44} \mathrm{H}_{80} \mathrm{O}_{8} \mathrm{P}$ & 826.56 & 598.496082 & & & \\
\hline & & & & $\mathrm{C}_{44} \mathrm{H}_{78} \mathrm{O}_{8} \mathrm{P}$ & 824.54 & 596.480432 & & & \\
\hline & & & & $\mathrm{C}_{44} \mathrm{H}_{76} \mathrm{O}_{8} \mathrm{P}$ & 822.53 & 594.464782 & & & \\
\hline
\end{tabular}

M: molecular species

three cultivars are listed in Table 4 and significant differences $(p<0.05)$ in their amounts can be observed among the studied cultivars at the two time-dates $(28$ and 55 DAP). At immature stage (28 DAP) and in bitter apricot, the ESI-MS spectra of PG revealed one molecular species ion with $\mathrm{m} / \mathrm{z} 771$ corresponding to PG C18:0C18:3 specie $(11.7 \%)$ (Tables 3 and 4$)$. However, in sweet one, six molecular species ions of $\mathrm{PG}$ with $\mathrm{m} / \mathrm{z} 721,745,747,769,771$ and 773 were revealed with PG C16:0C18:1 specie(14.5\%) identified as main molecular species in PG. In semi-sweet apricot case, PG with $\mathrm{m} / z$ 721, 743, 745, 769, 771 and 773 were detected with a predominance of PG C18:1C18:3 specie (16.7\%) (Tables 3 and 4). At this stage, semi-sweet and bitter ones were the richest varieties in $\mathrm{PG}$ fraction with values of $8.2 \%$ PL in comparison to $5.4 \%$ (55 DAP) in sweet one (Table 1). This content is similar to those founded in olive oil ${ }^{27)}$. At full maturity, bitter apricot revealed four molecular species of $\mathrm{PG}(\mathrm{m} / z 745,747,749$ and 773) with PG C16:0C18:0 (13\%) and PG C18:0C18:0(13\%) as main compounds (Table 4). In sweet and semi-sweet va- 


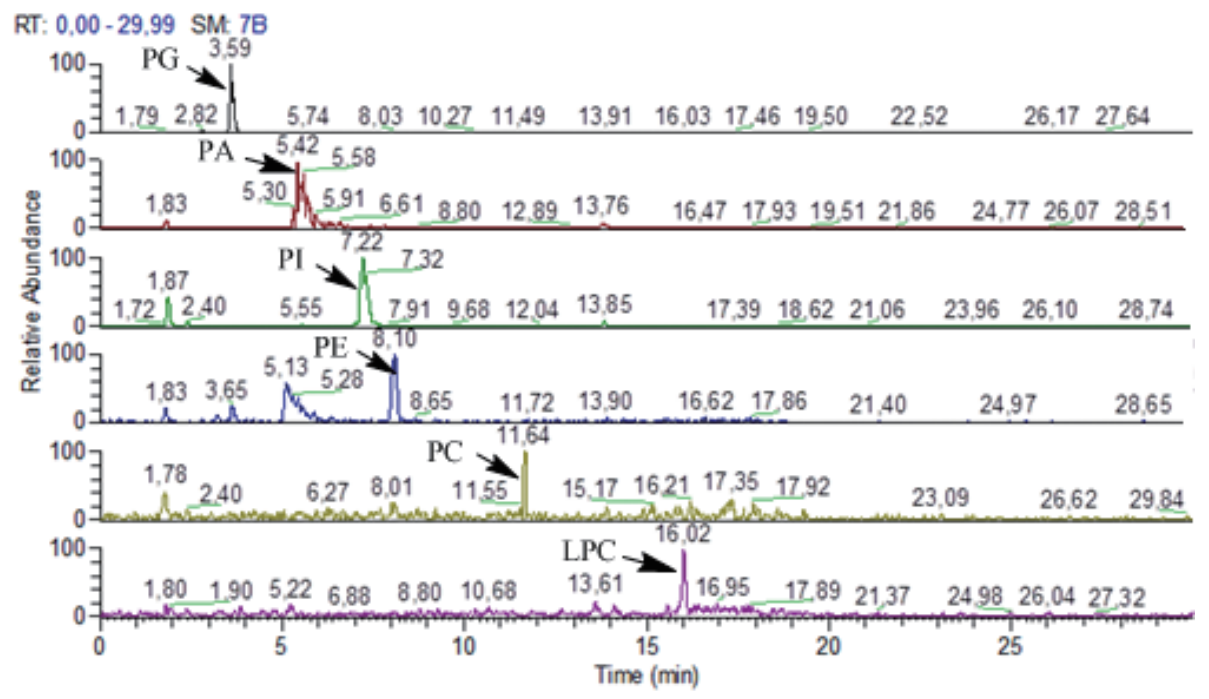

Fig.2 extracted ion chromatograms (EICs) of phospholipid classes for apricot seed oil (sweet apricot or AprC) obtained by LC/ESI-MS in negative ion mode.

rieties, five $(\mathrm{m} / z 745,747,769,773$ and 775$)$ and eight $(\mathrm{m} / \mathrm{z}$ 743, 745, 747, 749, 769, 771, 773 and 775) molecular species ions of $\mathrm{PG}$ were detected respectively with $\mathrm{PG}$ C16:0C18:2(12.3\%) specie as the major class of PLs in sweet one whereas PG C16:0C18:1(13.2\%) and PG C16:0 $\mathrm{C} 18: 3(13.0 \%)$ as the major ones in semi-sweet apricot too (Tables 3 and 4). As a result, at this time date, bitter apricot was the richest $(p<0.05)$ variety in PG fraction with a value of $9.8 \%$ comparatively to 6.2 and $7.5 \%$ in semisweet and sweet ones respectively (Table 1). Given those results, we suggest that at immature stage, fatty acids as stearic (C18:0), oleic (C18:1) and linolenic (C18:3) are the predominant in $\mathrm{PG}$ apricot oil. Whereas, at maturity, palmitic (C16:0), oleic (C18:1) and linoleic (C18:2) fatty acids are the major ones which is confirmed by Table 2 and according our results founded in apricot fatty acids composition (Table 2). During maturity, we observed differences in content accumulation of major molecular species of PG on the three varieties which can be explained by genetical and biotope differences.

3.3.2 Phosphatidic acid (PA)

The membrane lipid biosynthesis cycle needs the presence of phosphatidic acid or PA which lead cell multiplication and signal transduction ${ }^{9)}$. The pretreatment with PA-rich diets may prevent several ulcers ${ }^{28)}$. In bitter apricot and at immature stage, PA fraction revealed four molecular species $(m / z 669,671,695$ and 697) (Table 3) with PA C16:0C18:3 as predominant species (45\%) (Table 4). However, sweet and semi-sweet apricots revealed respectively five and three molecular species of PA with also a predominance of PA C18:0C18:3 specie (29\%) (Table 4) in sweet apricot and 33\% in semi-sweet one) (Table 4). At full maturity, bitter apricot revealed three molecular species of PA with the same predominance of PA
C16:0C18:3(30.7\%) (Table 4). As for as semi-sweet apricot, the results revealed three molecular species with a predominance of PA C16:0C18:3(29\%). Furthermore, in sweet apricot, the PA C16:0C18:3 species was also dominant with a percentage of $32.5 \%$ (Table 4 ). Table 1 show that the content of the three varieties on PA do not exceed $11 \%$ and $2 \%$ at immature and full maturity stages respectively. PA in apricot oil was less abundant than in other oilseeds such as sunflower (46\%) and almond (45\%) oils ${ }^{9)}$. Contrary to PG classes and during maturity, the three varieties show the same predominant molecular species with different content apricot. Kuiper ${ }^{29)}$ proved that the variations in PA content are essentially due to the temperature variations. Other authors have suggested that PA is a minor component and its content increase speedily in response to cell stimulation ${ }^{9)}$. In fact, the PA classes serves as a precursor in the biosynthetic pathways of phospholipids ${ }^{10)}$.

3.3.3 Phosphatidylinositol(PI)

Phosphatidylinositol or PI is a metabolic precursor of polyphosphoinositides implied also in cell cycle progression and signal transduction ${ }^{9)}$. In immature stage (28 DAP), 4 molecular species of $\mathrm{PI}(\mathrm{m} / z$ 809, 837, 859 and 863) (Tables 3 and 4$)$ were revealed in bitter apricot with PI C18:0C18:3 (25\%) compound as major one. At the same stage, there is also a predominance of PI C18:0C18:3 specie (20\%) for sweet and a PI C16:0C18:3 specie (23\%) for semi-sweet apricot respectively (Table 4). At full maturity (55 DAP), the content of PI for the three cultivars decreases with an abundance of the same class of PLs such as PI C18:0C18:3 specie with a maximum reached with $15.2 \%$ for semisweet apricot (AprO) (Table 4). The oleic acid (C18:2) formed the most abundant molecular species in the two stages of PI fraction. The content of PI reached $22.3 \%$ in $28 \mathrm{DAP}$ (sweet apricot). However, this latter attempted 
Table 4 Composition of the different molecular species of phospholipids in Apricot oil kernels (\% of total phospholipids $\pm \mathrm{SD})^{\mathrm{a}}$ at two different maturity.

\begin{tabular}{|c|c|c|c|c|c|c|}
\hline \multirow[t]{2}{*}{ Molecular species (\%) } & \multicolumn{2}{|c|}{ AprB } & \multicolumn{2}{|c|}{ AprO } & \multicolumn{2}{|c|}{ AprC } \\
\hline & IS & MS & IS & MS & IS & MS \\
\hline \multicolumn{7}{|c|}{$P G(\%$ of total $P G)$} \\
\hline PG-C16:0/16:0 $(\mathrm{m} / \mathrm{z}$ 721.50) & nd & nd & $14.5 \pm 0.4^{\mathrm{a}}$ & nd & $12.3 \pm 0.7^{\mathrm{b}}$ & nd \\
\hline PG-C16:0/18:3 $(\mathrm{m} / z$ 743.50) & nd & nd & $11.2 \pm 0.1^{\mathrm{a}}$ & $13.0 \pm 1.1^{\mathrm{b}}$ & nd & nd \\
\hline PG-C16:0/18:2 (m/z 745.5) & nd & $11.0 \pm 0.1^{\mathrm{b}}$ & $16.5 \pm 0.3^{\mathrm{a}}$ & $11.7 \pm 1.2^{\mathrm{b}}$ & $12.8 \pm 0.1^{\mathrm{b}}$ & $12.3 \pm 0.4^{\mathrm{b}}$ \\
\hline PG-C16:0/18:1 $(m / z 747.5)$ & nd & $11.9 \pm 0.4^{\mathrm{b}}$ & nd & $13.2 \pm 0.4^{\mathrm{b}}$ & $14.5 \pm 0.3^{\mathrm{b}}$ & $1.0 \pm 0.1^{\mathrm{b}}$ \\
\hline PG-C16:0/18:0 (m/z 749.5) & nd & $12.9 \pm 0.4^{\mathrm{b}}$ & nd & $11.0 \pm 1.5^{\mathrm{b}}$ & nd & nd \\
\hline PG-C18:1/18:3 (m/z 769.5) & nd & nd & $16.7 \pm 0.1^{\mathrm{a}}$ & $10.4 \pm 0.1^{\mathrm{a}}$ & $10.7 \pm 0.1^{\mathrm{a}}$ & $0.5 \pm 0.4^{\mathrm{c}}$ \\
\hline PG-C18:0/18:3 (m/z 771.5) & $11.7 \pm 0.1^{\mathrm{a}}$ & nd & $11.7 \pm 0.2^{\mathrm{a}}$ & $11.5 \pm 0.1^{\mathrm{a}}$ & $9.3 \pm 0.5^{\mathrm{a}}$ & nd \\
\hline PG-C18:0/18:2 ( $m / z$ 773.5) & nd & nd & nd & $12.1 \pm 0.1^{\mathrm{b}}$ & nd & nd \\
\hline PG-C18:0/18:0 $(m / z$ 773.5) & nd & $13.0 \pm 0.6^{\mathrm{b}}$ & $14.3 \pm 0.1^{\mathrm{a}}$ & $12.6 \pm 0.7^{\mathrm{b}}$ & $12.3 \pm 0.5^{\mathrm{a}}$ & $0.8 \pm 0.4^{\mathrm{b}}$ \\
\hline PG-C18:0/18:1 $(m / z$ 775.5) & nd & nd & nd & nd & nd & $1.8 \pm 0.1^{\mathrm{b}}$ \\
\hline \multicolumn{7}{|c|}{$P A(\%$ of total $P A)$} \\
\hline PA-C16:0/18:3 (m/z 669.5) & $45.0 \pm 0.4^{\mathrm{a}}$ & $0.7 \pm 0.1^{\mathrm{b}}$ & $33.0 \pm 1.4^{\mathrm{a}}$ & $29.1 \pm 0.4^{\mathrm{b}}$ & $29 \pm 0.6^{b}$ & $32.5 \pm 0.2^{\mathrm{a}}$ \\
\hline PA-C16:0/18:2 ( $m / z$ 671.5) & $6.3 \pm 1.4^{\mathrm{a}}$ & nd & nd & nd & $9.4 \pm 0.6^{\mathrm{b}}$ & nd \\
\hline PA-C16:0/18:1 ( $m / z$ 673.5) & nd & nd & $4.0 \pm 0.8^{b}$ & nd & $0.5 \pm 0.4^{c}$ & $0.6 \pm 0.4^{\mathrm{a}}$ \\
\hline PA-C16:0/18:0 ( $m / z$ 675.5) & nd & $3.2 \pm 0.1^{\mathrm{b}}$ & nd & nd & nd & nd \\
\hline PA-C18:1/18:3 ( $\mathrm{m} / \mathrm{z} 695.47)$ & $5.2 \pm 0.3^{b}$ & nd & nd & $21.1 \pm 0.9^{\mathrm{b}}$ & $17.4 \pm 0.4^{\mathrm{c}}$ & $5.8 \pm 0.1^{b}$ \\
\hline PA-C18:0/18:3 ( $\mathrm{m} / \mathrm{z}$ 697.48) & $6.0 \pm 0.6^{\mathrm{b}}$ & $4.6 \pm 1.0^{\mathrm{a}}$ & $7.6 \pm 0.9^{\mathrm{a}}$ & $8.2 \pm 0.2^{\mathrm{b}}$ & $18.8 \pm 0.3^{\mathrm{b}}$ & $12.3 \pm 0.2^{\mathrm{b}}$ \\
\hline PA-C18:0/18:1 $(m / z 701.5)$ & nd & nd & nd & nd & nd & $0.8 \pm 0.37^{\mathrm{c}}$ \\
\hline \multicolumn{7}{|c|}{$P E(\%$ of total PE) } \\
\hline PE-C16:0/18:2 ( $/ \mathrm{z} 714.51)$ & nd & nd & nd & nd & $14 \pm 0.22^{b}$ & $27 \pm 0.1^{\mathrm{c}}$ \\
\hline PE-C18:0/18:3 ( $\mathrm{m} / \mathrm{z} 740.32)$ & $11.9 \pm 0.4^{\mathrm{a}}$ & $21.2 \pm 0.4^{\mathrm{a}}$ & nd & $14.2 \pm 1.3^{\mathrm{a}}$ & nd & nd \\
\hline PE-C18:0/18:2 ( $\mathrm{m} / \mathrm{z} 742.54)$ & nd & nd & nd & nd & nd & $21.3 \pm 0.1^{\mathrm{b}}$ \\
\hline PE-C18:1/18:0 ( $\mathrm{m} / \mathrm{z} 744.56)$ & $12.4 \pm 0.5^{\mathrm{b}}$ & $22.6 \pm 0.2^{\mathrm{a}}$ & nd & nd & $10.2 \pm 1.2^{\mathrm{a}}$ & $21.7 \pm 0.1^{\mathrm{b}}$ \\
\hline PE-C18:1/18:3 ( $\mathrm{m} / \mathrm{z} 738.51)$ & nd & nd & nd & nd & $18.8 \pm 0.3^{\mathrm{b}}$ & $25.5 \pm 1.1^{\mathrm{a}}$ \\
\hline PE-C18:0/18:0 ( $\mathrm{m} / \mathrm{z} 744.55)$ & nd & $12.1 \pm 0.3^{\mathrm{a}}$ & $11.1 \pm 0.3^{\mathrm{a}}$ & $11.5 \pm 0.1^{\mathrm{a}}$ & nd & $10.5 \pm 1.2^{\mathrm{a}}$ \\
\hline \multicolumn{7}{|c|}{ PI (\% of total PI) } \\
\hline PI-C16:0/16:0 ( $m / z$ 809.52) & $11.6 \pm 0.5^{b}$ & nd & nd & nd & nd & nd \\
\hline PI-C16:0/18:2 ( $m / z$ 833.52) & nd & nd & nd & nd & $1.6 \pm 0.7^{\mathrm{a}}$ & nd \\
\hline PI-C16:0/18:1 ( $m / z$ 835.53) & nd & nd & $13.9 \pm 0.5^{\mathrm{a}}$ & nd & nd & nd \\
\hline PI-C16:0/18:0 ( $/ / z$ 837.55) & $11.4 \pm 0.1^{\mathrm{b}}$ & nd & nd & nd & nd & nd \\
\hline PI-C16:0/18:3 ( $m / z$ 831.50) & nd & nd & $23.1 \pm 1.3^{\mathrm{a}}$ & $10.3 \pm 1.5^{\mathrm{a}}$ & nd & nd \\
\hline PI-C18:1/18:3 $(\mathrm{m} / \mathrm{z} 857.52)$ & nd & nd & $22.4 \pm 1.3^{\mathrm{c}}$ & $10.3 \pm 1.5^{\mathrm{a}}$ & nd & nd \\
\hline PI-C18:0/18:3 ( $\mathrm{m} / \mathrm{z} 859.33)$ & $25.3 \pm 0.1^{\mathrm{a}}$ & $11.2 \pm 0.2^{\mathrm{a}}$ & $21.2 \pm 1.5^{\mathrm{c}}$ & $15.2 \pm 0.7^{\mathrm{a}}$ & $20.2 \pm 0.3^{\mathrm{a}}$ & $11.6 \pm 0.2^{\mathrm{a}}$ \\
\hline PI-C18:0/18:1 $(\mathrm{m} / \mathrm{z} 863.56)$ & $5.4 \pm 0.2^{\mathrm{a}}$ & nd & nd & nd & nd & nd \\
\hline \multicolumn{7}{|c|}{$P C(\%$ of total $P C)$} \\
\hline PC-C16:0/18:3 ( $\mathrm{m} / \mathrm{z} 800.54)$ & nd & $47.3 \pm 0.1^{\mathrm{a}}$ & nd & $48.2 \pm 0.1^{\mathrm{d}}$ & nd & $40.0 \pm 0.2^{\mathrm{d}}$ \\
\hline PC-C16:0/18:2 ( $\mathrm{m} / \mathrm{z} 802.56)$ & nd & $31.5 \pm 0.1^{\mathrm{b}}$ & nd & $31.9 \pm 0.7^{\mathrm{a}}$ & nd & $12.6 \pm 0.8^{\mathrm{c}}$ \\
\hline PC-C16:0/18:1 ( $\mathrm{m} / \mathrm{z} 804.58)$ & $6.4 \pm 1.3^{\mathrm{a}}$ & $31.9 \pm 0.1^{b}$ & nd & $33.3 \pm 0.4^{\mathrm{a}}$ & nd & $34.9 \pm 0.2^{\mathrm{a}}$ \\
\hline PC-C18:1/18:3 ( $\mathrm{m} / \mathrm{z} 826.56)$ & nd & $36.4 \pm 1.3^{\mathrm{a}}$ & nd & $21.0 \pm 0.3^{\mathrm{a}}$ & $12.7 \pm 0.3^{\mathrm{c}}$ & $21.7 \pm 0.1^{\mathrm{b}}$ \\
\hline PC-C18:1/18:1 ( $\mathrm{m} / \mathrm{z} 830.39)$ & nd & nd & nd & nd & nd & $1.0 \pm 0.1^{\mathrm{b}}$ \\
\hline PC-C18:0/18:1 $(\mathrm{m} / \mathrm{z} 832.61)$ & $12 \pm 0.7^{\mathrm{a}}$ & nd & nd & nd & nd & nd \\
\hline PC-C18:0/18:0 $(\mathrm{m} / \mathrm{z} 834.62)$ & nd & nd & nd & nd & nd & $0.9 \pm 0.2^{b}$ \\
\hline \multicolumn{7}{|l|}{ 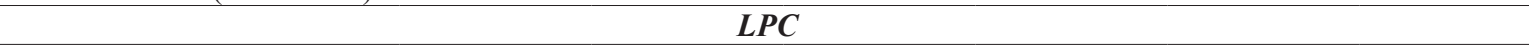 } \\
\hline LPC C16:0 $(m / z)$ & $6.8 \pm 0.6^{\mathrm{a}}$ & $27.0 \pm 0.5^{b}$ & $9.2 \pm 0.5^{\mathrm{a}}$ & $14.4 \pm 0.1^{\mathrm{b}}$ & $10.6 \pm 1.2^{c}$ & $24.5 \pm 1.1^{\mathrm{c}}$ \\
\hline LPC C18:0 $(m / z)$ & $0.5 \pm 0.3^{\mathrm{a}}$ & $10.8 \pm 0.9^{b}$ & $0.8 \pm 0.4^{\mathrm{a}}$ & $2.0 \pm 0.3^{b}$ & $0.2 \pm 0.1^{\mathrm{a}}$ & $1.2 \pm 0.1^{\mathrm{a}}$ \\
\hline LPC C18:1 $(m / z)$ & nd & nd & nd & $0.3 \pm 0.1^{\mathrm{a}}$ & $2.3 \pm 0.3^{\mathrm{a}}$ & $0.3 \pm 0.1^{\mathrm{a}}$ \\
\hline LPC C18:2 $(m / z)$ & $2.1 \pm 0.1^{\mathrm{a}}$ & $1.0 \pm 0.3^{\mathrm{a}}$ & nd & $1.4 \pm 0.3^{\mathrm{a}}$ & $9.2 \pm 0.1^{\mathrm{b}}$ & $1.4 \pm 0.4^{\mathrm{a}}$ \\
\hline LPC C18:3 $(\mathrm{m} / \mathrm{z})$ & $0.53 \pm 0.4^{\mathrm{a}}$ & $0.1 \pm 0.1^{\mathrm{a}}$ & nd & $0.1 \pm 0.3^{\mathrm{a}}$ & nd & $0.2 \pm 0.1^{\mathrm{a}}$ \\
\hline
\end{tabular}

Mean values with different letters within a column of the same variety are significantly different, at $p \leq 0.05$. ${ }^{a}$ Each value is a mean \pm standard deviation (SD) of a triplicate analysis performed on different samples. Nd: not detected. IS: immature stage (28 DAP), MS: full maturity stage (55 DAP). AprB: apricot Bargoug; AprC: apricot Chechi Bazza; AprO: apricot Oud Rhayem. 
38.9\% (highest value) in bitter apricot at full maturity (55 DAP). Differences of content in PG and PI observed, may be explained by the fact that PG and PI were produced from phosphatidate via the same enzymatic complex cytidine diphosphate-diacylglycerol (CDP-DAG) pathway (Fig. $1)^{10)}$. We suggest that CDP-DAG was converted preferentially to PI by CDP-DAG rather than PG. This hypothesis agrees with previous results also showing that PI was present in high content in flax ${ }^{26)}$.

\subsubsection{Phosphatidylethanolamine (PE)}

Generally, the membrane of plant tissues contains high levels of Phosphatidylethanolamine or PE. This class of PLs is known to have an interesting antioxidant activity ${ }^{9)}$. In bitter apricot and at immature stage (28 DAP), two major molecular species $(740,744)$ (Tables 3 and 4 ) were revealed with a predominance of PE C18:1C18:0 compound $(12.4 \%)$. In the two grafted apricot varieties, the analysis revealed highest levels for PE C18: 0C18:0(11\%) and PE C18:1C18:3 (19\%) respectively in semi-sweet and sweet apricots (Table 4). Similarly, at maturity stage (55 DAP), the same molecular specie was predominant ( $\mathrm{PE}$ C18:1C18:0(22.6\%)) in bitter apricot. Otherwise, in the two grafted ones more molecular were revealed especially in sweet one (Table 4) such as PE C18:0C18:3(14\%) and PE C16:0C18:2(27\%)identified as main molecular species for semi-sweet and sweet apricots respectively. In apricot oil, $\alpha$-Linolenic (C18:3), oleic (C18:1) and stearic acids (C18:0) are the most abundant acids in PE at the two stages of maturity. The sweet one is the richest cultivar on PE fraction at these time-dates (Table 4). With regard to PE results, we did not observe the presence of phosphatidyl serine (PS) as class PLs fraction in our apricot varieties. This could be explained by the fact that PS may later be decarboxylated to PE by the high activity of phosphatidylserine decarboxylase in apricot oil ${ }^{24)}$, or by the absence of both phosphatidylserine synthase. Later and during maturation, $\mathrm{PE}$ may be methylated to $\mathrm{PC}$ by the action of $\mathrm{N}$ methyltransferases (Fig. 1).

3.3.5 Phosphatidylcholine (PC)

Phosphatidylcholine or PC is the precursor of bioactive lipid mediators used essentially in the treatment of some neurological liver diseases ${ }^{9)}$. Consequently, PC plays a vital role in liver and cell functions and is a substitute to choline chloride which are commonly used in nutritional supplements $^{30)}$. At immature stage (28 DAP), the ESI-MS spectra of PC revealed only PC C18:0C18:1(12\%) specie and PC C18:1C18:3(13\%) compound in bitter and sweet apricots respectively. However, at full maturity, a maximum of PC C16:0C18:3 specie (48\%) was reached in semi-sweet apricot compared to $47 \%$ and $40 \%$ in bitter and sweet apricots respectively (Table 4). Indeed, apricot (especially semi-sweet one) is a rich cultivar in PC fraction mainly at full maturity stage (Table 4). The most abundant PC species in all cultivars apricot contain polyunsaturated fatty acids such as $\alpha$-Linolenic (C18:3) and oleic (C18:1) acids. Table 1 shows that PC attempt $62 \%$ at immature and full maturity stages. Our results are confirmed by Zlatanov and Janakieva ${ }^{7}$ on apricot oils with $43 \%$ of PC content and in Chinese apricot ${ }^{6)}$. Obviously, the predominant molecular species, are those containing the following fatty acids C16:0, C18:3, C18:1 and C18:2. High content of linoleic as $\omega-6$ was observed in our samples and is required by humans for various physiological functions ${ }^{6)}$. Also, high levels of oleic and linoleic acids in PL classes could have good nutritional implications. Furthermore, the high content of PC in apricot oil concludes that it is an appropriate and convenient phospholipid sources ${ }^{7)}$. Consequently, with their high content of PC, bitter and semi-sweet apricots seem to be the most therapeutic apricots and could have beneficial health properties during maturity and especially at full maturity. Additionally, the efficacity of PC containing polyunsaturated fatty acids in the activation of liver metabolism and enhanced memory has been proved ${ }^{6,24)}$. 3.3.6 Lysophosphatidylcholine (LPC)

Leaon ${ }^{31}$ reported potential health benefits of Lysophosphatidylcholine (LPC). This latter is considered as an important bioactive compound in jojoba meal ${ }^{31)}$. During maturity, our results revealed that the major molecular specie was LPC C16:0 specie with highest content reached in sweet apricot (10.6\%) and bitter one (27\%) at immature and full maturity stages respectively (Table 4). Since, the LPC is the hydrolysis products of PC by phospholipase $\mathrm{A}_{2}{ }^{32}$. We could suggest that this enzyme was more active in sweet and bitter apricots than in semi-sweet one. Our results at full maturity are slightly similar(Table 1) with those reported in the Egyptian apricot seed oils ${ }^{5)}$ where PC represented the main PL (62 versus $72 \%$ ) and LPC the minor one ( 7 versus $3 \%)$ respectively. These minor differences could be explained by the fact that the content of PLs in plants depends on different parameters such as hormones, climatic conditions, edaphic conditions, and genetic differences ${ }^{3)}$. However, the differences observed in the content of different classes of GPLs could be the consequence of fatty acid's distribution in GPLs biosynthesis, including acylation and desaturation enzymes activities.

\section{Conclusion}

Genetic diversity influenced the FA composition and the molecular species of PLs in the three distinct apricot varieties. The profile of their distributions among maturity was found to differ substantially with different molecular species abundancy. According to the results obtained, in 28 DAP, wild (Bargoug) apricot represents an interesting profile in PC bioactive compounds. Likewise, at full maturity (55 DAP), semi-sweet (Oud Rhayem) represents an attractive source in PA, PE and PC classes. It could 
suggest that Tunisian apricot varieties could be considered at these two time-dates, as a potential natural source of PC for condiments in food industry. As a result, this study could successfully be used in apricot breeding situations, which are a good source of natural bioactive compounds of PC that might be incorporated into functional foods and nutraceuticals industrial applications.

\section{Acknowledgements}

The authors would like gratefully to acknowledge Dr. L. Krichen at higher institute of applied biological sciences of Tunis for species identification. They thank Mr. L. FRIHA (Testour) and Mr. L. DLIGGA (Oasis of Gafsa) for providing apricot kernels and their technical assistance in conducting the culture of the different varieties of apricot. As well as, the authors would thank Mrs. I. HERRING for the English revision of the final version of the manuscript.

\section{References}

1) Wani, S.M.; Nusrat, J.; Touseef, A.W., Mukhtar; A., Masoodi, F.A.; Adil, G. Optimization of antioxidant activity and total polyphenols of dried apricot fruit extracts (Prunus armeniaca L.) using response surface methodology. J. Saudi Soc. Agric. Sci. 16, 119-126 (2015).

2) Krichen, L.; Audergon; J.M., Trifi-Farah, N. Assessing the genetic diversity and population structure of Tunisian apricot germplasm. Sci. Hortic. 172, 86-100 (2014).

3) Krichen, L.; Audergon, J.M.; Trifi-Farah, N. Relative efficiency of morphological characters and molecular markers in the establishment of an apricot core collection L. Hereditas 149, 163-172(2012).

4) Krichen, L.; Mnejja, M.; Aru, P.; Marrakchi, M.; TrifiFarah, N. Use of microsatellite polymorphisms to develop an identification key for Tunisian apricots. Genet. Resour. Crop. Ev. 53, 1699-1706 (2006).

5) Abd El Aal, M.H.; Khalil, M.K.M. Apricot kernel oil: characterization, chemical composition and utilization in some baked products. Food Chem. 19, 287-298 (1986).

6) Guo, B.Y.; Wen, B.; Shan, X.Q.; Zhang, S.Z.; Lin, J.M. Separation and determination of phospholipids in plant seeds by nonaqueous capillary electrophoresis. J. Chromatogr. A 1074, 205-213(2005).

7) Zlatanov, M.; Janakieva. I. Phospholipid composition of some fruit-stone oils of Rosaceae species. Eur. J. Lipid. Sci. Technol. 100, 312-315(1998).

8) Restuccia, D.; Spizzirri, U.G.; Puoci, F.; Cirillo, G.; Vinci, G.; Picci, N. Determination of phospholipids in food samples. Food Rev. Int. 28, 1-46 (2012).

9) Zitouni, M.; Wever, V.; Dormann, P.; Abdelly, C.; Ben Youssef, N. Quadrupole time-of -flight mass spectrometry analysis of glycerophospholipid molecular species in the two haplophyte seed oils: Eryngium maritimum and Cakile maritima. Food Chem. 213, 319328(2016).

10) Lei Liu, D.; Waters, L.E.; Terry, J.R.; Jinsong, B.; Graham, J.K. Phospholipids in rice: Significance in grain quality and health benefits: A review. Food Chem. 139, 1133-1145(2013).

11) Yoshida, H.; Tanigawa, T.; Yoshida, N.; Kuriyama, I.; Tomiyama, Y.; Mizushina Y. Lipid components, fatty acid distributions of triacylglycerols and phospholipids in rice brans. Food Chem. 129, 479-484 (2011).

12) Karlander, S.G.; Karlsson, K.A.; Pascher, I. Analysis of polar parts of phospholipids. N -demethylation of choline-containing lipids for gas chromatography and mass spectrometry. Biochim. Biophys. Acta 326, 174-183 (1973).

13) Bernhard, W.; Linck, M.; Creutzburg, H.; Postle, A.D.; Arning, A.; Martin-Carrera, I.; Sewing, K.F. High-performance liquid chromatographic analysis of phospholipids from different sources with combined fluorescence and ultraviolet detection. Anal. Biochem. 220, 172-180 (1994).

14) Brouwers, J.F. Liquid chromatography -mass spectrometric analysis of phopholipids. Chromatography, ionization and quantification. Biochim. Biophys. Acta 1811, 763-777(2011).

15) Bamba, T.; Shimonishi, N.; Matsubara, A.; Hirata, K.; Nakazawa, Y.; Kobayashi, A.; Fukusaki, E. High throughput and exhaustive analysis of diverse lipids by using supercritical fluid chromatography -mass spectrometry for metabolomics. J. Biosci. Bioeng. 105, 460-469 (2008).

16) Shrivas, K.; Tapadia, K. Ionic liquid matrix-based dispersive liquid-liquid microextraction for enhanced MALDI-MS analysis of phospholipids in soybean. $J$. Chromatogr. B 1001, 124-130 (2015).

17) Xiong, Y.; Zhao Y.Y.; Curtis J.M. Measurement of phospholipids by hydrophilic interaction liquid chromatography coupled to tandem mass spectrometry: The determination of choline containing compounds in foods. J. Chromatogr. A 1218, 5470-5479(2011).

18) Folch, J.; Lees, M.; Sloane Stanley, G.M. A simple method for the isolation and purification of total lipids from animal tissues. J. Biol. Chem. 226, 497-509 (1957).

19) Bligh, E.G.; Dyer, W.J. A rapid method of total lipid extraction and purification. J. Physiol. Biochem. 37, 911-917 (1959).

20) Douce R. Identification et dosage de quelques glycérophosphosphatides dans des souches nor- 
males et tumorales de scosonères cultivés in vitro. Vol. 259, C.R. Academic Science, pp. 3066-3068. (1964).

21) Mectalfe, L.D.; Schmitz, A.A.; Pellka, J.R. Rapid preparation of fatty acids esters from lipids for gas-chromatographic analysis. Analyt. Chem. 38, 514-515 (1966).

22) Lechvallier D. Les lipides des Lemnacées, analyse des acides gras des lipides des frondes de Spirodela polyrhiza. Vol. 263, Comptes Rendus de l'Académie des Sciences, pp.1848-1852(1966).

23) Yang Z.; Parrish C.C.; Helleur R.J. Automated gas chromatographic method for neutral lipid carbon number profiles in marine samples. J. Chromatogra. Sci. 34, 556-568(1996).

24) Harrabi, S.; Herchi, W.; Kallel, H.; Mayer, P.M.; Boukhchina, S. Mass spectrometric analysis of glycerophospholipids in corn oil. Food Chem. 114, 712-716 (2009).

25) Khotimchenko, S.V.; Vaskovsky, V.E.; Titlyanova, T.V. Fatty acids of marine algae from the pacific coast of North California. Bot. Mar. 45, 17-22 (2005).

26) Herchi, W.; Sakouhi, F.; Sebei, K.; Xiong, Y.; Boukhchina, S.; Kallel, H.; Curtis, J.M. Characterization of the glycerophospholipid fraction in flaxseed oil using liquid chromatography- mass spectrometry. Food Chem.
129, 437-442 (2011).

27) Koprivnjak, O.; Majetic, V.; Malenica Staver, M.; Lovric, A.; Blagovic, B. Effect of phospholipids on extraction of hydrophilic phenols from virgin olive oils. Food Chem. 119, 698-702 (2010).

28) Tanaka, T.; Morito, K.; Kinoshita, M.; Ohmoto, M.; Urikura, M.; Satouchi, K.; Tokumura, A. Orally administered phosphatidic acids and lysophosphatidic acids ameliorate aspirin-induced stomach mucosal injury in mice. Digest. Dis. Sci. 58, 950-958(2013).

29) Kuiper, P.G.C. Environmental changes and lipid metabolism of higher plants. Physiol. Plantarum 64, 118-122 (1985).

30) Reddy, J.R.C.; Vijeeta, T.; Karuna, M.S.L.; Rao, B.V.; Prasad, R.B.N. Lipase catalyzed preparation of palmitic and stearic acid-rich phosphatidylcholine. J. Am. Oil Chem. Soc. 82, 727-730(2005).

31) Leaon, F.; Van Boven, M.; De Vitte, P.; Busson, R.; Cokelaere, M. Isolation and identification of molecular species of phosphatidylcholine and lysophosphatidylcholine from jojoba seed meal (Simmondsia chinensis). J. Agric. Food Chem. 52, 1207-1211 (2004).

32) Kent, C. Regulatory enzymes of phosphatidylcholine biosynthesis: A personal perspective. Biochim. Biophys. Acta 1733, 53-66(2005). 